\title{
RODENTS SURVEY AND THEIR ESTIMATION TO SOME MAIN FIELD CROPS IN TWO DIFFERENT LOCATION At GIZA GOVERNORATE. Waleed A.S. Soefy ${ }^{1}$; Talat M. S. Kashta ${ }^{2}$ and Ahmed A. R. Al-Gendy ${ }^{1}$
}

1- Agric. Zoology \& Nematology Dept., Faculty of Agric. Al-Azhar University. Cairo. 2- Harmful Animals Dept., plant protection Instituted. Agric. Res. Center, Dokki, Giza.

Key Words: Rodent- damage- wheat - maize.

\section{ABSTRACT}

This work proved the presence of three Genera viz.; $R$. rattus (Linn.) followed by $R$. norvegicus Berk., A. niloticus (Desm.) and Mus musculus Linn., belonging to two genera (Rattus and Mus) from family Muridae, were recorded in kerdasa and Osim distracts at Giza governorate. Thronghant two successive years 2015 and 2016 A.D. The damage caused by rats in wheat fields during the whole repin stages; (milky, pasty, dough and mature stages). The obtained results cleared that rate of damage increased during the pasty stage then decreased during the mature stage. The rodent damage percentage for 2015 and 2016 were $(9.14 \%, 6.78 \%)$ and $(12.81 \%$ and $6.07 \%)$ in kerdasa and Osim distracts respectively. Whereas, the rodents damage estimation in their crop fields was conducted during the full size pod, full size seed and mature stages. The calculated rodent damage percentage in maize crop fields were, $(1.49 \%$ and $1.45 \%)$ and $(2.59 \%$ and $0.92 \%)$ in kerdasa and Osim distracts respectively. Maize was exposed to high rodent infestation during the full size seed stage more than the previous or later stages. The damage of rodents to field crops may be depends upon the growth stage.

\section{INTRODUCTION}

The seasonal changes were studied in rat's population by Kansouth et al. (1990) in Dahshour locality at Giza Governorate and Hussien (1991) at Fayoum Governorate. Asran et al. (1991) estimated the damage caused by the Nile grass rat A. niloticus (Desm.), on wheat, broad bean, chamomile and garlic in three locations at Fayoum Governorate during 1987-1988. They showed that, wheat was the most preferred crop to A. niloticus (Desm.), comparing with the broad bean and chamomile while caused damage on garlic was negligible. Ejaz Ahmad et al. (1995) estimated the annual grain losses/shop due to rats consumption, contamination, spillage, and wastage to be $740 \mathrm{~kg} / \mathrm{shop}$. The annual losses would approximate about $0.3 \%$ of the estimated 1225 million $\mathrm{mt}$ that move through the markets yearly. Santra et al. (2001) estimated the damage caused by Indian house rat Rattus rattus (Linnaeus), brown or sewer rat Rattus norvegicus (Berkenhout), house 
mouse Mus musculus Linnaeus, and Large bandicoot rat Bandicota indica Bechstein, in three districts of West Bengal. House rat Rattus rattus (Linnaeus) was the most dominant rodents which caused excessive damage on field and stored crops at West Bengal. The damages made by these rodents were approximately $5-6 \%$ paddy in the field and $7 \%$ in the stores; $6-7 \%$ (Potato and Wheat) and 1-8\% other crops.

This manuscript aims to evaluate the rodent damage to some main field crops such as wheat and maize.

\section{MATERIALS AND METHODS}

The studies are consisted of the field trials, which conducted under the field conditions in two different locations at which belong to Embaba district, Giza governorate.

\section{Field studies locations: -}

Kerdasa and Osim villages in Embaba district at Giza governorate were selected for the field trials. They are located about $25 \mathrm{~km}$ far from northern of Giza pyramids, and occupied about 10000 feddans. Old cultivated lands, they are cultivated with tomato, wheat, horse bean, cabbage, kidney bean and squash in Winter, and with peanut, eggplant, maize and pepper in Summer and they are also cultivated with mandarin, palm and mango orchards.

\section{Rodent species survey: -}

The survey studies were conducted during two agriculture years 2015 and 2016 in different locations at Giza governorate.

25 live traps with spring doors were used for three consecutive nights. Traps were supplied with tomato, lanshon and taameia and were distributed in the mentioned places in the evening, then were collected next morning. The captured individuals were identified and classified according to Osborn and Helmy (1980).

\section{Rodent population density: -}

During the period from two agriculture years 2015 and 2016 in different locations at Embaba district Giza Governorate. 25 live traps were monthly used for two consecutive nights. Traps distributed at fields were supplied with tomato, taameia and lanshon. Traps were cleaned before use with hot water and liquid soap, then provided with fresh food materials. They were set-up in the evening at 05.00 P.M. and were ingathered in the next morning at 07.00 A.M.

Number of rodents caught a month

$$
\text { Population density } \%=\overbrace{\text { Traps' number } \times \text { nights' number }}^{X} 100
$$


Captured animals were transferred in tight cloth bag and inserted into a jar provided with a piece of cotton wool wetted with chloroform to anesthetizing rodents. Rodents were counted then classified according to Osborn and Helmy (1980). Species, subspecies, sex, maturity status of males and females were recorded. Mature females were also dissected to determine if they pregnant or not. Rodents' population structure in fields, animal buildings and houses were studied. Monthly population density was estimated all the year round as last equation.

\section{Damage caused by rodents in fields:-}

Field damage assessment was done in kerdasa and Osim villages at Embaba district, Giza governorate, during 2014 to 2017 seasons. Damage caused by rats was achieved in areas cultivated with different field crops . a-Wheat

Three fields were selected, one feddan each. In each field, 15 samples were selected diagonally and were determined by using wooden frame $(100 \times 100 \mathrm{~cm})$. Samples were taken during milky, doughy and mature stages of wheat. In each sample, the number of damaged and undamaged tillers inside the frame were counted, and the percentage of damage was calculated according to Poch et al., (1982) as follows:

Number of damaged tillers

Damage $\%=$ X 100

Total number of tillers counted

\section{b. Maize}

In this study, three feddans were selected to estimate the damage in 10 samples were checked, the sample size was 30 consecutive plants which are selected randomly from one row, the distance in between rows was $1 / 10$ the filed width. Ten samples were checked. The size of the sample was 30 cobs. Cobs were divided to healthy, 25\% damaged, 50\% damaged, $75 \%$ damaged and $100 \%$ damaged. The damage percentage was calculated as follows:

$$
\mathrm{A} \times 0+\mathrm{B} \times 0.25+\mathrm{C} \times 50+\mathrm{D} \times 0.75+\mathrm{E} \times 1
$$

Damage $\%=$

Total number of sampled plants

Where:
A: healthy plants
B: Plants with $25 \%$ damage
C: Plants with $50 \%$ damage 
D: Plants with $75 \%$ damage

E: Plants with $100 \%$ damage

\section{RESULTS AND DISCUSSION}

\section{1-Survey and distribution: -}

Survey and distribution of some rodent species and subspecies were carried out under field conditions from some habitats, at two different locations at Embaba district Giza governorate during two agriculture Season of 2014 - 2015 and 2015 - 2016 A.D.

This work proved the presence of three Genera viz.; $R$. rattus (Linn.) followed by $R$. norvegicus Berk., A. niloticus (Desm.) and Muss musculus Linn., belonging to two genera (Rattus and Mus) from family Muridae, were recorded in kerdasa and Osim distracts at Giza governorate (Table,1) according to the full description of rodent species of Egypt adopted by Osborn and Helmy (1980) as the following:-

Kingdom: Animalia

Subkingdom: Metazoa

Phylum: Chordata

Subphylum: Vertebrata

Class: Mammalia

Subclass: Theria

Infraclass: Eutheria

Order: Rodentia

Suborder: Myomorpha

Family: Muridae

Subfamily: Murinae

Genera:

i-Rattus Fischer, 1803

a- $R$. rattus (Linnaeus, 1758)

b- $\boldsymbol{R}$. norvegicus Berkenhout, 1767

ii-Mus Linn. M. musculus Linnaeus, 1758.

iii- Arvicanthis A. niloticus (Desm.)

The recorded data in table (1) revealed that osim district have a havier deresity more than Kerdasa district. Also proved that $R$. Rattus was the most dominant one followed by $R$. norvegicus, Mus musculus and A. niloticus for each of field crops and vegetable crops during the whole experimental period which comprised two successive years 2015 and 2016 A.D. 
Table (1): Survey of rodents in different locations at Giza governorate during two agriculture years 2014

\begin{tabular}{|c|c|c|c|c|c|c|c|c|c|c|c|c|}
\hline \multirow{2}{*}{ Genera } & \multirow{2}{*}{$\begin{array}{c}\text { Common } \\
\text { name }\end{array}$} & \multirow{2}{*}{ Scientific name } & \multirow{2}{*}{ Locations } & \multicolumn{3}{|c|}{$\begin{array}{l}\text { Field } \\
\text { crops }\end{array}$} & \multicolumn{3}{|c|}{$\begin{array}{c}\text { Vegetable } \\
\text { crops }\end{array}$} & \multicolumn{2}{|c|}{$\begin{array}{c}\text { Total } \\
\text { rodent numbers }\end{array}$} & \multirow{2}{*}{ Avarage } \\
\hline & & & & $\begin{array}{c}1^{\text {st }} \\
\text { year }\end{array}$ & $\begin{array}{c}2^{\text {nd }} \\
\text { year }\end{array}$ & Av. & $\begin{array}{c}1^{\text {st }} \\
\text { year }\end{array}$ & $\begin{array}{l}2^{\text {nd }} \\
\text { year }\end{array}$ & Av. & $1^{\text {st }}$ year & $2^{\text {nd }}$ year & \\
\hline \multirow{4}{*}{ 1-Rattus } & \multirow{2}{*}{$\begin{array}{c}\text { Black- } \\
\text { bellied rat }\end{array}$} & \multirow{2}{*}{ R. rattus } & kerdasa & 4 & 7 & 5.5 & $\mathbf{0}$ & 5 & 2.5 & 4 & 12 & 8.0 \\
\hline & & & Osim & 29 & 2 & 15.5 & 13 & 4 & 8.5 & 42 & 6 & 24.0 \\
\hline & \multirow{2}{*}{ Norway rat } & \multirow{2}{*}{ R. norvegicus } & kerdasa & 6 & 9 & 7.5 & 7 & 18 & 12.5 & 13 & 27 & 20.0 \\
\hline & & & Osim & $\mathbf{0}$ & 1 & 0.5 & $\mathbf{0}$ & 2 & 1.0 & $\mathbf{0}$ & 3 & 1.5 \\
\hline \multirow{2}{*}{ 2-Arvicanthis } & \multirow{2}{*}{ Nile rat } & \multirow{2}{*}{ A. niloticus } & kerdasa & 1 & 1 & 1.0 & 1 & 1 & 1.0 & 2 & 2 & 2.0 \\
\hline & & & Osim & 9 & 5 & 7.0 & 4 & 1 & 2.5 & 13 & 6 & 9.5 \\
\hline \multirow{2}{*}{ 3-Muss } & \multirow{2}{*}{ House mouse } & \multirow{2}{*}{ M. musculus } & kerdasa & 1 & 9 & 5.0 & 15 & 1 & 8.0 & 16 & 10 & 13.0 \\
\hline & & & Osim & $\mathbf{0}$ & $\mathbf{0}$ & 0.0 & $\mathbf{0}$ & 3 & 1.5 & $\mathbf{0}$ & 3 & 1.5 \\
\hline \multirow{2}{*}{\multicolumn{3}{|c|}{ Total No. of entrapped rodents $/ 25$ trips/ 3 nights }} & kerdasa & 12 & 25 & 18.5 & 23 & 25 & 24.0 & 35 & $\mathbf{5 0}$ & 42.5 \\
\hline & & & Osim & 38 & 8 & 23.0 & 17 & 10 & 13.5 & 55 & 18 & 36.5 \\
\hline
\end{tabular}




\section{Rodent range for some main filed crops:-}

The percentage in Tables 2 and 3 and Figures 1 and 2 should that percentage of damage which ceased by field rodents to each of wheat crop and maize crops during two successive years 2015 and 2016 in kerdasa and Osim districts thronghat their life in field at the whole different of growth stages. The rodent damage percentage in wheat were (9.14\% and $6.78 \%)$ for Kerdasa and $(12.81 \%$ and $6.07 \%)$ for Osim district for 2015 and 2016, respectively. Meanwhile the field rodents caused during in maize which was planted in kerdasa and osim less than which had happened in wheat crops in some locations.

Table (2) Damage caused by common rodents on wheat crop in kerdasa and Osim areas during 2015 - 2016 seasons.

\begin{tabular}{|c|c|c|c|c|c|}
\hline \multirow{2}{*}{ Area } & \multirow{2}{*}{ Season } & \multicolumn{3}{|c|}{ No. of the investigated plants } & \multirow{2}{*}{ Damage\% } \\
\cline { 3 - 5 } & & Intact one & Infested one & Total & \\
\hline \multirow{2}{*}{ kerdasa } & 2015 & 3545 & 357 & 3902 & 9.14 \\
\cline { 2 - 5 } & 2016 & 2997 & 218 & 3215 & 6.78 \\
\hline \multirow{2}{*}{ Osim } & 2015 & 3653 & 537 & 4190 & 12.81 \\
\cline { 2 - 5 } & 2016 & 2796 & 181 & 2977 & 6.07 \\
\hline
\end{tabular}

Table ( 3 ) Damage caused by common rodents on Maize crop in kerdasa and Osim areas during 2015 - 2016 seasons.

\begin{tabular}{|c|c|c|c|c|c|}
\hline \multirow{2}{*}{ Area } & \multirow{2}{*}{ Year } & \multicolumn{2}{|c|}{ No. of the investigated plants } & \multirow{2}{*}{ Damage $\%$} \\
\cline { 3 - 5 } & & Intact one & Infested one & Total & \\
\hline \multirow{2}{*}{ kerdasa } & 2015 & 2822 & 42 & 2864 & 1.49 \\
\cline { 2 - 5 } & 2016 & 2896 & 42 & 2938 & 1.45 \\
\hline \multirow{2}{*}{ Osim } & 2015 & 2973 & 77 & 3050 & 2.59 \\
\cline { 2 - 5 } & 2016 & 2721 & 25 & 2746 & 0.92 \\
\hline \multirow{2}{*}{ Area } & \multirow{2}{*}{ Year } & \multicolumn{2}{|c|}{ No. of the investigated plants } & \multirow{2}{*}{ Damage \% } \\
\cline { 2 - 5 } & & Intact one & Infested one & Total & 1.49 \\
\hline \multirow{2}{*}{ kerdasa } & 2015 & 2822 & 42 & 2864 & 1.45 \\
\cline { 2 - 5 } & 2016 & 2896 & 42 & 2938 & 2.59 \\
\cline { 2 - 5 } & 2015 & 2973 & 77 & 2746 & 0.92 \\
\hline
\end{tabular}

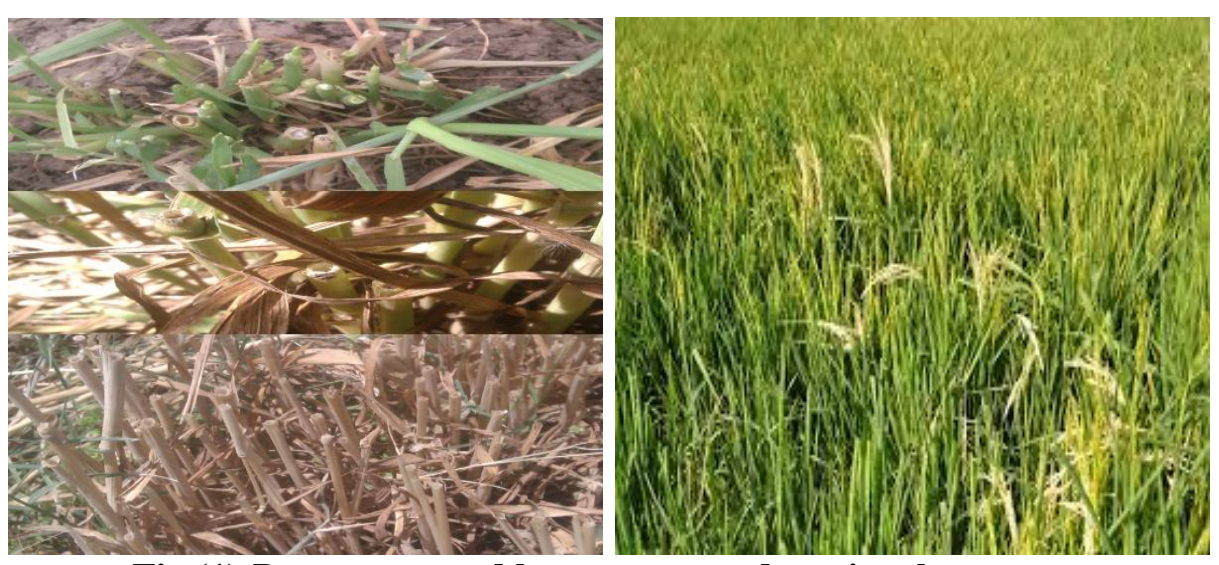

Fig.(1):Damage caused by common rodents in wheat crops 


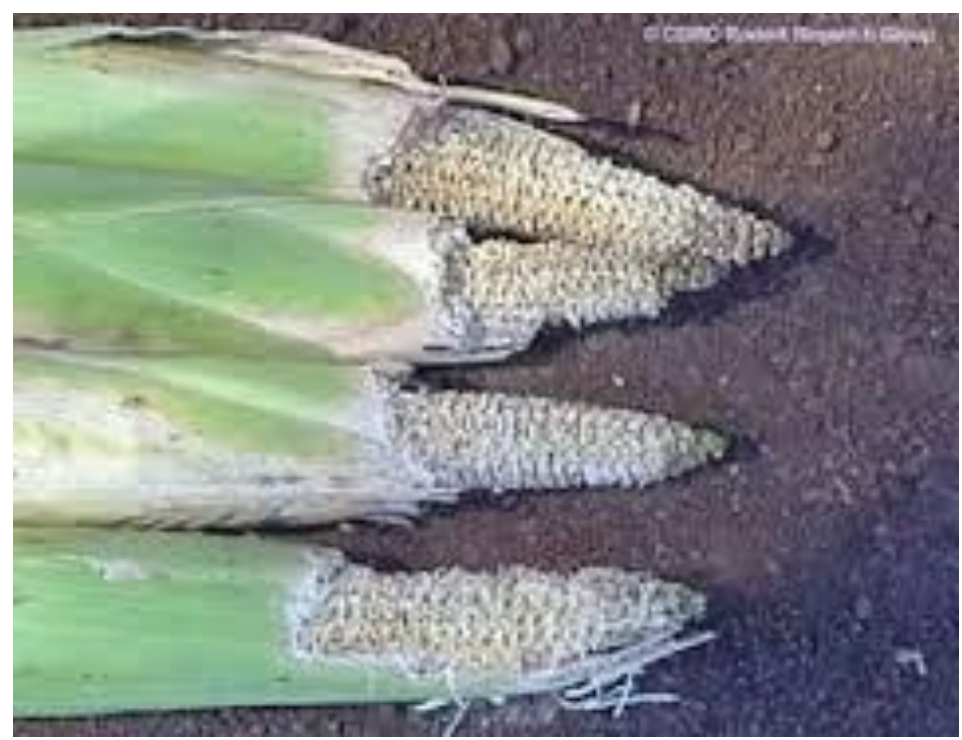

Fig (2) Rodent damage for maize crop

The previous results nearly confirmed with the next researchers; Asran et al. (1991), Ejaz Ahmed et al. (1995) and Sentra et al. (2001) who indicated that $R$. norvegicus Berk., have followed water steams and become firmly entrenched at garbage dumps at food processing places, and at farms where adequate food, water and harborage were available. Also, Kansouth et al., (1990) stated that, the domestic rodent species in Dahshour locality Rattus rattus alexandrinus, Rattus rattus frugivorus and Rattus norvegicus Berk., while Abdel-Wanis (2008) found that, Rattus norvegicus was the most dominant species followed by Rattus rattus frugivorous and Rattus rattus rattus respectively, whereas Rattus rattus alexandrines and Arvicanthis niloticus showed low percentage, respectively while Mus musculus was the lowest El- Mansoureia and Abd El-Samad villages in Embaba distract and Abd El-Halim et al., (2009) recorded that, Rattus norvegicus, Rattus rattus alexandrinus, Rattus rattus frugivourus, Acomys cahirinus and Mus musculus.

Damage caused by rats $R$. rattus on some field crops:-

a. Wheat: - Data presented in Table (3) showed the damage caused by rats in wheat fields during the milky, pasty (dough) and mature stages. It is obvious that rate of damage increased during the pasty stage then decreased during the mature stage as the damage percentage were $(9.14 \%, 6.78 \%)$ and $(12.81 \%$ and $6.07 \%)$ in kerdasa and Osim distracts respectively. The damage of rats to field crops may be depends upon the 
growth stage. These results are supported by Abdel-Karim (1991), who stated that most cereal crops are subjected to low infestation with rats during milky stage, increased drastically during dough stage and then decreased during mature stage. Brown (2005) mentioned that house mice, Mus domesticus, cause significant damage to wheat crops in Australia by digging up and eating newly planted seeds, or by cutting stems and eating developing grain.

b-Maize:- The damage caused by rats was conducted during the full size pod, full size seed and mature stages in maize fields. The percentage of were recorded damage $(1.49 \%$ and $1.45 \%)$ and $(2.59 \%$ and $0.92 \%)$ in kerdasa and Osim distracts respectively. Maize was exposed to high rodent infestation during the full size seed stage more than the previous or later stages. White et al. (1997) determined the damage caused by Rattus rattus (Linn.) to macadamia nut crops were from several Australian macadamia orchards during the 1995/1996 growing season. Both the extent and pattern of crop damage were associated with the type of adjacent non-crop habitat. Orchards adjacent to large, temporally stable, structurally complex habitats experienced high levels of rodent damage (mean 9.9\%). Front row trees adjacent to these stable habitats showed significantly higher damage than trees further into the orchard, suggesting an interaction between the crop and non-crop habitats. Orchards adjacent to highly modified grasslands and other orchard blocks exhibited the lowest levels of damage (mean $0.8 \%$ ), with the damage in these areas being uniformly distributed. Rattus rattus (Linn.) was the main rodent species responsible for the damage.

\section{REFERENCES}

Abd El-Halim, A.S.; K.A. Allam ; A.M. Metwally and A.M. El Boraey (2009): Seasonal variation of infestation rate with lice, tick and mite among rodents in certain Egyptian Regions. J. Egypt Soc., Parasitol.,39 (2):617-624.

Abdel -Karim, S.M. (1991): Studies on rodents in Sharkia Governorate. Ph.D. Thesis, Fac. Agric., Zagazig University. pp. 294.

Abdel-Wanis, M.A. (2008): Studies on some rodent in Egypt. M.Sc. Thesis, Fac., Agric., Cairo Univ., pp.111.

Asran, A.A.; H.I. El-Deeb and M.A. EL-Halafawy (1991): Rat damage to certain crops and population density of Arvicanthis niloticus in Fayuom Governorate. Egypt. J. Agric., Res., 69(1):273-279.

Brown, P. (2005): The effect of simulated house damage to wheat in Australia. Crop Protection., 24(2): 101-109. 
Ejaz Ahmed ; Iftikhar Hussain and Joe E. Brooks (1995). Losses of stored foods due to rats at grain markets in Pakistan. International Biodeterioration and Biodegradation, 36(1-2):125133

Hussien, S.S.M. (1991): Ecological studies and control of certain rodents in Beni-Suef Governorate. M.Sc. Thesis, Fac., Agric., Cairo Univ. pp. 103.

Kansouth, A.S.; M.S. El-Zemaity and M.W. Mikhail (1990): Population density of domestic rodents and associates fleas at Dahshour, Giza Governorate, Annual Agricultural Science, Faculty of Agriculture, Ain Shams University, Cairo, Egypt, 35 (1): $543-550$.

Osborn, D.J. and I. Helmy (1980): The contemporary land mammals of Egypt (including Sinai). Published by Field Museum of National History, London.

Poche, R.M. ; M.Y. Main,; R. Sterner; M.E. Haque, and P. Sultand, (1982): Rodent movements in wheat fields. Mammalia, 50: 165172.

Santra, K. B. ; M. Khalua, and C.K. Manna (2001): Rodent population : Nature and extent of damages of agricultural crops depending upon different ecological conditions of the Gangetic plane of West Bengal. Proceedings of the Zoological Society Calcutta, 54 (1):68-72.

White K.P. ; P.Hurban ; T. Watanabe and D.S. Hogness (1997): Coordination of Drosophila metamorphosis by two ecdysoneinduced nuclear receptors. Science., 276: 114-117

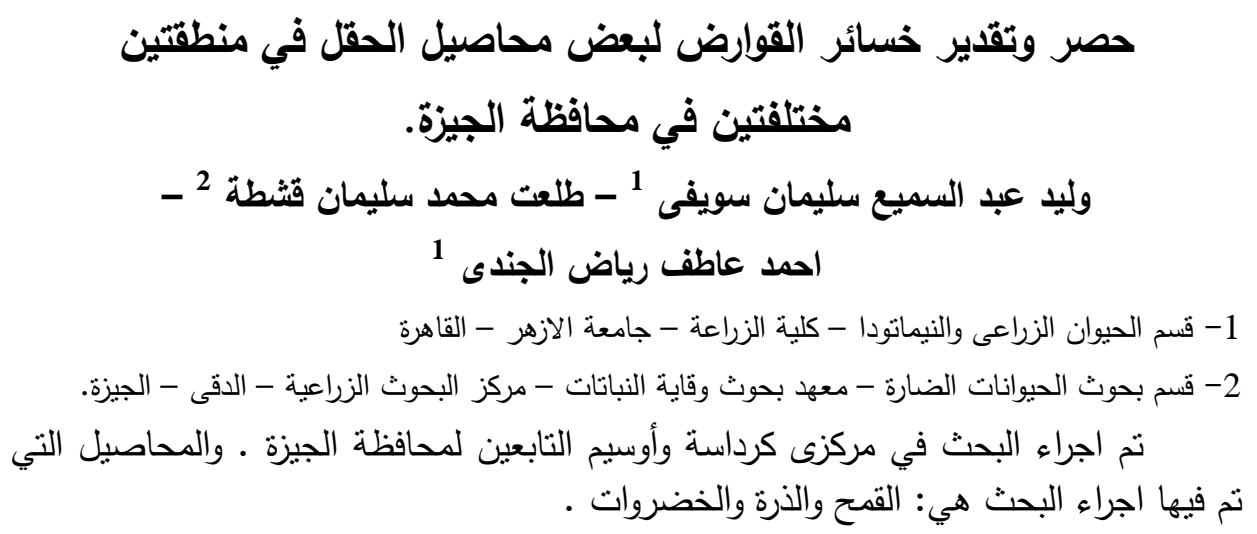


الدراسات الخاصة بالحصر كانت في جميع المحاصيل المذكورة اما تقدير الخسائر

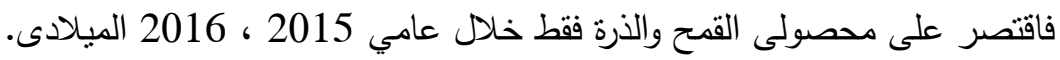

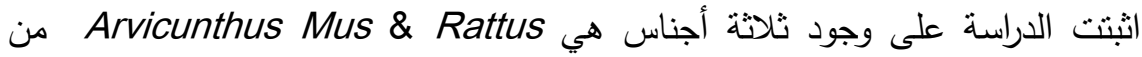

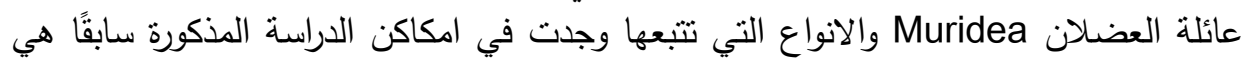
Mus musculus بالإضافة للانواع و A. niloticus \& R. rattus

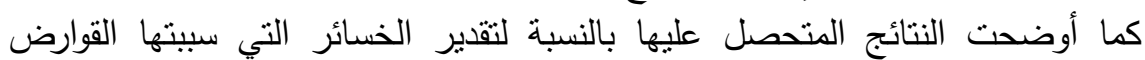

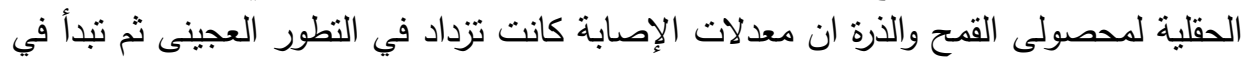

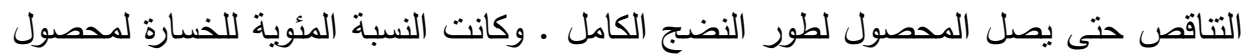

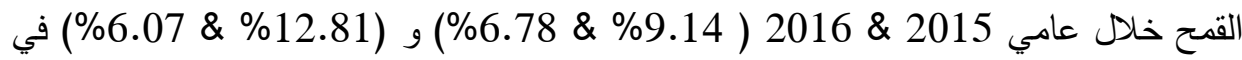
كلا من مركزى كرداسة واوسيم على النوالي بينما بلغت الخسارة في محصول الذو \&

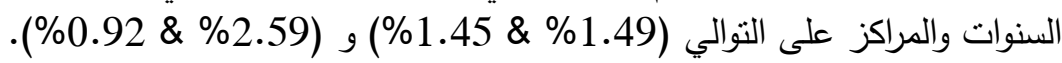

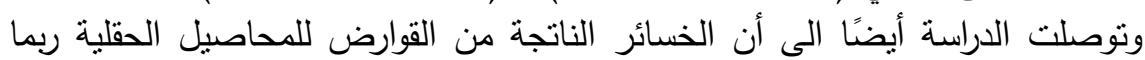
تتوقف على طور النمو للمحصول. 